\title{
MODIFICATION OF CELL MEMBRANE IN VARIANTS OF CHINESE HAMSTER CELLS RESISTANT TO ABRIN
}

\author{
I-CHIAN LI.' DIANE A. BLAKE, ${ }^{2}$ IRWIN J. GOLDSTEIN² and ERNEST H. Y. CHU' \\ Departments of 'Human Genetics and 'Biological Chemistrv, University' of Michigan Medical School, \\ Ann Arbor, MI 48109, USA
}

\begin{abstract}
SUMMARY
Stable and heritable variants of Chinese hamster ovary (CHO) cells which are resistant to different levels $(0.1,1.0$ and $10 \mu \mathrm{g} / \mathrm{ml})$ of the toxin abrin have been isolated and characterized. The frequency of resistant colonies to abrin was increased with the concentration of a chemical mutagen. There was no effect of cell density or cross-feeding on the recovery of variants. In experiments using fluorescein-labeled abrin and ricin which bind to terminal (non-sialylated) galactose residues of cell-surface oligosaccharides, parental cells exhibited strong binding toward both toxins, whereas no fluorescence was observed in the resistant clones. A fluorescein-conjugated lectin, BS II, which is specific for terminal $N$-acetyl-D-glucosaminyl residues, did not interact with the parental cells, but did with the resistant clones. This suggests that on the surface of resistant cells the number of terminal galactosyl residues of oligosaccharide chains in glycoproteins was reduced, exposing the penultimate $N$-acetyl-D-glucosaminyl residues. The number of available endogenous acceptor sites for galactosyl transferase in the abrin-resistant clones was directly proportional to the degree of resistance. In the presence of great excess of exogenous acceptor, the rates of galactosyl transfer were similar in all the abrin-resistant cell types tested, with levels ranging from 1.4 to 1.7 times parental cell values. Studies with tetraploid cell hybrids reveal that resistance was a recessive trait. Fluctuation analysis showed that abrin resistance occurred in $\mathrm{CHO}$ cell populations at a rate of $4-7 \times 10^{-8} / \mathrm{cell} /$ generation. The system may serve as a new marker for quantitative mutagenesis studies.
\end{abstract}

Several mammalian cell lines resistant to the cytotoxic action of a variety of plant lectins and toxins have been isolated [1-6]. The resistance is due mainly to altered oligosaccharides on the cell membrane, which results in a decreased binding of the lectins or toxins. These variants have been used to elucidate the biological role and mode of assembly of cell surface glycoproteins $[7,8]$.

The protein abrin from the jequirity bean (Abrus precatorius) is extremely toxic to animals. It causes hemorrhage in the intestine, multiple necroses in the liver and kidney, and degeneration of myofibrils in myocardium [9]. The mechanism of action of the toxin is now well understood $[10,11]$. The toxin molecule consists of two polypeptide chains, A and B, each serving a different function. The $B$ chain binds to cell surface glycoprotein receptors and, through this interaction facilitates the endocytosis of the A chain into the cell. The A chain is an enzyme which inactivates the GTPase in $60 \mathrm{~S}$ ribosomal subunit, thus inhibiting cellular protein synthesis.

Cell variants resistant to abrin may be very uscful for studies of the structure of membrane glycoproteins and/or the genetic control of protein synthesis. To our knowledge, no such variants have yet been reported, although those resistant to low con- 
centrations of another plant toxin, ricin. have been isolated from HeLa cells [12] and Chinese hamster ovary (CHO) cells [ 1 . 39] and are found to be cross-resistant to abrin $[13,14]$.

Abrin and ricin appear to have the same mechanism of action and both bind to the similar oligosaccharide chains containing terminal galactosyl residues [9]. However. the structures of the two toxins are not identical [9], nor are their immunochemical properties [15] or their isoelectric points. The carbohydrate-binding properties of the toxins are similar but not identical [1618]. Abrin has a higher affinity for galactose than for lactose $[16,18]$. The opposite is true for ricin [40]. The binding sites of the toxins may recognize more than a single monosaccharide determinant.

In this study, we describe the isolation of variants of Chinese hamster ovary ( $\mathrm{CHO}$ ) cells which are resistant to abrin and display a marked alteration in toxin-binding properties. The carbohydrate composition of the membranes isolated from the resistant cells appears to be different from that of the parental cells. In whole-cell assay of protein synthesis. the variants show sensitivity to the inhibitory effect of abrin. though to a lesser extent than the parental cells. The system responds well to mutagen and may serve as a new marker for quantitative mutagenesis studies.

\section{MATERIALS AND METHODS}

\section{Cell culture and cell lines}

Wild-type and abrin-resistant $\mathrm{CHO}$ cells were grown in modified Eagle's minimum essential medium, supplemented with $5 \%$ fetal calf serum (FCS) (Gibco, Grand Island, N.Y.). $1 \mathrm{mM}$ sodium pyruvate, 1.5 times the normal levels of vitamins and essential amino acids and 2 times non-essential amino acids. Cells were grown at $37^{\circ} \mathrm{C}$ in a humidified air with $5 \% \mathrm{CO}_{2}$.

$\mathrm{CHO}-\mathrm{K} 1 \mathrm{~T} 1$ is a diphtheria toxin-resistant cell line derived from a proline auxutroph (CHO-K1). This cell line was originally isolated in this laboratory by
Dr Wayne Stanlev and was used as the parental line to isolate abrin-resistant (Abrit variants. Gatl is at mutant elone of CHO cell auxotrophic for glycine. adenosine and thymidine. It was isolated hy M.Burney \& Whitmore [19] and given w w hy Dr Larrs Thompson.

\section{Toxins and lertins}

Abrin, ricin, and their tluorescein-labeled conjugates were purchased from Sigma Chemical Co. BS II lectin was isolated and purified by the method of Ebisu \& Goldstein [20]. This lectin interacts with non-reducing terminal $\alpha$ - and $\beta$-linked $N$-acetyl-1)-glucosaminyl residues and. in contrast to wheat germ agglutinin (WGA), does not bind $2 \mathrm{~V}$-acetyl-D-glucosaminyl residues which are internally situated in the oligosaccharide chain [18].

\section{Mutagen treatment and variant selection}

Cells were seeded into $100 \mathrm{~mm}$ plastic plates at a concentration of $1 \times 10^{6}$ cells/plate. Six hours later ethyl methanesulfonate (EMS) was added to plates to give a final concentration of $100-400 \mu \mathrm{g} / \mathrm{ml}$. After a $17 \mathrm{~h}$ treatment, cells were washed. grown and transferred when necessary in normal medium for 2-12 days to allow the expression of the variant phenotype.

For the selection of variants, about $5 \times 10^{5}$ cells (mutagen-treated and control) were plated per $100 \mathrm{~mm}$ plate in normal medium containing appropriate concentrations of abrin. Surviving colonies were picked or scored atter $10-14$ days. No change of selective medium was necessary. The frequencies of resistant colonies were measured after correcting for plating efficiencies of the cells.

By this single-step selection, clones resistant to $2 x$ $10^{-3} .1 \times 10^{-2}$ and $1 \times 10^{-1} \mu \mathrm{g} / \mathrm{ml}$ of abrin were isolated. Further selection at higher concentrations of abrin was carried out on some of those clones resistant to $1 \times$ $10^{-1} \mu \mathrm{g} / \mathrm{ml}$ of abrin. Clones D4-1. D4- $a$ and D4-1 $b$ were resistant to 1.5 and $10 \mu \mathrm{g} / \mathrm{ml}$ of abrin, respectively.

\section{Cell hybridization}

Three $\mathrm{Abr}^{\mathrm{r}}$ clones $\left(\mathrm{Gat}^{+} \mathrm{Pro}^{-}\right.$) resistant to different levels of abrin were mixed. $1 \times 10^{r}$ each, with equal number of $\mathrm{Gat}^{-} \mathrm{Pro}^{+}$cells and exposed to $\beta$-propiolactone-inactivated Sendai virus. The fused and unfused cells were plated at $2 \times 10^{5} / 100 \mathrm{~mm}$ plate in a selective medium lacking proline, adenine and thymidine. Only hybrid clones which were $\mathrm{Gat}^{+} \mathrm{Pro}^{+}$could grow in the selective medium.

\section{Whole-cell protein synthesis assay}

Cells were inoculated into $16 \mathrm{~mm}$ diameter wells in 24-well plates and incubated at $37^{\circ} \mathrm{C}$ for 2 days. The medium was aspirated and new medium deficient for leucine and containing different concentrations of abrin was added. After $24 \mathrm{~h}$ incubation, $\left[{ }^{14} \mathrm{C}\right]$ leucine at $0.4 \mu \mathrm{Ci} / \mathrm{ml}$ was added and incubation continued for another hour. The medium was removed, and the cells 


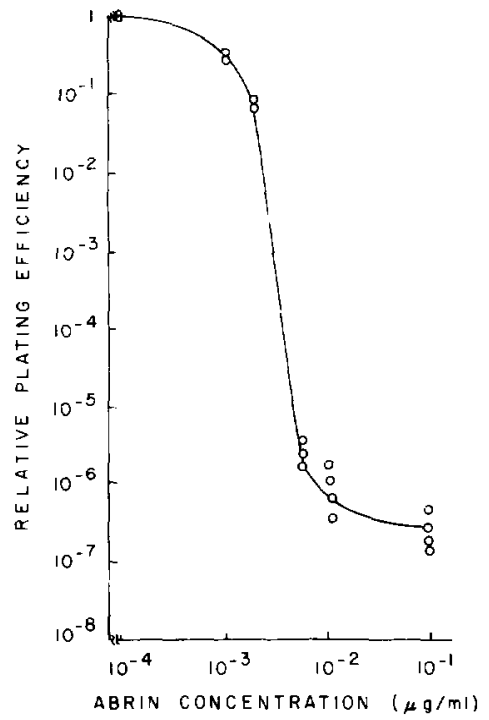

Fig. 1. Plating efficiency of $\mathrm{CHO} \mathrm{Kl}-\mathrm{Tl}$ cells as a function of the concentration of abrin in the culture medium (combined results from five replicate experiments).

washed with PBS and lysed with $0.1 \mathrm{~N} \mathrm{NaOH}$. To the ecll lysates $10 \%$ trichloroacetic acid (TCA) was added and the protein precipitates were collected on Whatman fiberglass discs. The filter discs were washed twice with $5 \%$ TCA, dried, and counted for radioactivity in a Tricarb scintillation spectrometer.

\section{Labeling cells with fluorescein isothiocyanate (FITC)-toxins}

Cells were grown as monolayers in $35 \mathrm{~mm}$ plastic dishes each containing a microscopic coverslip. The cells were washed with Dulbecco's phosphate buffered saline (DPBS) and incubated at $4^{\circ} \mathrm{C}$ for $1 \mathrm{~h}$ in a 50 $\mu \mathrm{g} / \mathrm{ml}$ of FITC-toxin solution, with or without $20 \mathrm{mM}$ of a competing sugar. After incubation, the cells were washed three times with DPBS, and observed under a fluorescence microscope. For quantitative measurements of fluorescence, the cells were immersed in DPBS containing $20 \mathrm{mM}$ of a competing sugar, galactose or lactose, plus $5 \mu \mathrm{g} / \mathrm{ml}$ of unlabeled carrier toxin and incubated at $4^{\circ} \mathrm{C}$ for $1 \mathrm{~h}$ in the dark. This treatment eluted the bound toxin from the cells into the wash buffer. The wash buffer containing the eluted FITC-toxin was measured for fluorescence in a fluornmeter.

\section{Preparation of crude membrane fraction for enzyme assay}

Cells were grown to confluency in Blake culture bottles $\left(170 \mathrm{~cm}^{2}\right.$ surface area), washed and scraped from the bottles into cold PBS. The cells were pelleted by centrifugation and suspended in a buffer which was ten times the original volume of the packed cells and contained $0.25 \mathrm{M}$ sucrose, $5 \mathrm{mM}$ Tris- $\mathrm{HCl}, \mathrm{pH} 7.4$, and $0.2 \mathrm{mM} \mathrm{MnCl}$. The cell suspension was placed in a nitrogen pressure bomb (Antisans Inc. Waltham. Mass.) and equilibrated for $20 \mathrm{~min}$ at $600 \mathrm{psi}$ of nitrogen. The cells were extruded from the bomb and an aliquot of the cell suspension was examined under the phase microscope to insure that at least $90 \%$ of the cells had been ruptured. Five minutes after ex-

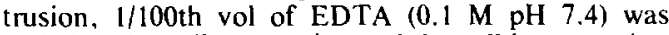
added to the cell suspension and the cell lysate underwent centrifugation at $20000 \mathrm{~g}$ for $20 \mathrm{~min}$ to pellet unbroken cells. nuclei, and mitochondria. The supernatant from the first centrifugation was centrifuged at $100000 \mathrm{~g}$ for $1 \mathrm{~h}$ to pellet a crude membrane fraction. This fraction, resuspended in $0.25 \mathrm{M}$ sucrose $1 \mathrm{mM}$ Tris- $\mathrm{HCl}$, $\mathrm{pH} 7.0-0.5 \mathrm{mM} \mathrm{MnCl}$, was used for subsequent galactosyl transferase assays.

\section{Assay of galactosyl transferase activity and preparations of exogenous acceptors}

Fetuin (Gibco) was coupled to CNBr-activated Sepharose (Pharmacia, Uppsala, Sweden) according to the manufacturer's instructions. The final product contained approx. $10 \mathrm{mg}$ fetuin $/ \mathrm{ml}$ of packed wet gel. A portion of the fetuin-Sepharose conjugate was treated sequentially with neuraminidase (Clostridium perfringens, Sigma Type V) and $\beta$-galactosidase (Aspergillus niger. Calbiochem B grade) to yield a final product which had lost $34 \%$ of the terminal sialic acid and $10.3 \%$ of penultimate galactose residues in the oligosaccharide side chains. Thus $10.3 \%$ of the oligosaccharide side chains in this glycoprotein preparation contained non-reducing terminal $N$-acetyl-Dglucosaminyl residues [21]. Release of sialic acid and galactose from the fetuin-Sepharose conjugate was monitored by thiobarbituric acid assay [22] and galactose dehydrogenase assay [23]. respectively.

Galactosyl transferase assays were carried out in a final volume of $200 \mu \mathrm{l}$ which contained $0.4 \mu \mathrm{Ci}$ UDP-[" $" \mathrm{C}]$ galactose (New England Nuclear, $289 \mathrm{mCi} /$ mmole), $20 \mathrm{mM}$ Tris-maleate, $\mathrm{pH} 7.0,2 \mathrm{mM} \mathrm{MnCl}$. $0.5 \%$ Triton $\mathrm{X}-100$, and $500 \mu \mathrm{g}$ crude membrane protein. An aliquot ( $50 \mu \mathrm{l}$ packed volume) of the asialoagalactofetuin conjugate was added to each assay. Aliquots $(20 \mu l)$ of the assay mixture were spotted onto $1 \times 23$ inch strips of Whatman No. I paper at various time intervals after the start of the reaction and the paper strips were developed by descending paper chromatography for $17 \mathrm{~h}$ in Solvent A [ $N$-butanol: glacial acetic acid: $1 \mathrm{M}$ ammonia $(2: 3: 1)]$. In this solvent system ${ }^{14} \mathrm{C}$-labeled glycoproteins remain at the origin, while the substrate, UDP-[ $\left.{ }^{14} \mathrm{C}\right]$ galactose. migrates down the paper strip [24]. The origins of the paper chromatograms were counted in a Packard Tricarb scintillation counter to monitor transfer of galactose to endogenous acceptors present in the crude membrane fraction.

Transfer to exogenous asialoagalactofetuin was monitored by washing the immobilized acceptor free of UDP- $\left[{ }^{4} \mathrm{C}\right]$ galactose and counting an aliquot of the ${ }^{14} \mathrm{C}$-labeled fetuin-Sepharose conjugate. Details of this procedure will be described elsewhere [25]. 
Table 1. Average frequencies $\left(\times 10^{- \text {ii }}\right)$ of spontaneous and indaced change's to abrin resistance in $\mathrm{CHO}$ cells

\begin{tabular}{|c|c|c|}
\hline \multirow{2}{*}{$\begin{array}{l}\text { EMS } \\
\text { conc." } \\
(\mu \mathrm{g} / \mathrm{ml})\end{array}$} & \multicolumn{2}{|c|}{ Abrin concentration $(\mu \mathrm{g} / \mathrm{m})$ ) } \\
\hline & $1 \times 10^{-2}$ & $1 \times 10^{-1}$ \\
\hline 0 & 1.4 & 0.4 \\
\hline 100 & 73.4 & 12.2 \\
\hline 200 & 104.7 & 33.1 \\
\hline 400 & 298.3 & 105.4 \\
\hline
\end{tabular}

\section{RESULTS}

\section{Abrin cytotoricity}

The initial experiments were aimed to determine the suitable concentrations of abrin to use for selection. The cytotoxicity of abrin against wild-type CHO-Kl cells is shown in fig. 1. Abrin is extremely toxic to CHO cells: The cell survival as measured by plating efficiency was decreased to less than $10^{-5}$ at abrin concentrations as low as $5 \times 10^{-3} \mu \mathrm{g} / \mathrm{ml}$. Beginning at approx. I $\times$ $10^{-2} \mu \mathrm{g} / \mathrm{ml}$ of abrin, the surviving fraction reaches a plateau at the level of $2-5 \times 10^{-6}$. Results of selection experiments with both untreated and EMS-treated cells in the presence of two concentrations of abrin are shown in table 1. Depending on the concentrations of abrin used, the frequency of resistant clones was increased 70-300-fold or 10-100-fold over the control after EMS treatment.

A random sample of clones that appeared in the presence of different concentrations of the toxin were isolated, grown in toxinfree medium, and retested for their resistance. All five clones examined in this way were resistant to abrin and the phenotype remained stable after growth for more than 300 generations in the absence of the toxin. Survival of three typical resistant

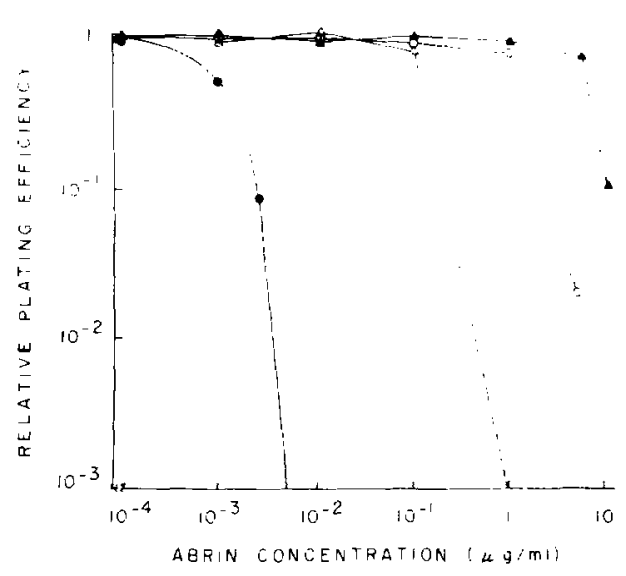

Fig. 2. Dose-response curves of wild-type and $\mathrm{Abr}$ $\mathrm{CHO}$ cells in the presence of abrin. $\mathrm{CHO} \mathrm{KI}$ TI: $\triangle, 6 \mathrm{~A} 3 ; 0 . \mathrm{D} 4-1 ; \Delta, \mathrm{D} 4-1 a$.

clones (6A3, D4-1, and D4-1 b), as compared to that of the parental cell line. is shown in fig. 2. Clone $6 \mathrm{~A} 3$ was isolated after a single-step selection at $1 \times 10^{-1} \mu \mathrm{g}$ / $\mathrm{ml}$ of abrin. At $1 \mu \mathrm{g} / \mathrm{ml}$. the plating efficiency of this clone dropped sharply to less than $1 \times 10^{-3}$. Similar results were found for clones D4-1 and D4-l $a$, which were isolated at higher concentrations of abrin, indi-

Table 2. Recovery of preformed Abrr variants in the concurrent presence of varying number of sensitive cells ${ }^{a}$

\begin{tabular}{lll}
$\begin{array}{l}\text { No. of } \mathrm{Abr}^{\mathrm{r}} \\
\text { cells }\end{array}$ & $\begin{array}{l}\text { No. of Abr: } \\
\text { cells }\end{array}$ & $\begin{array}{l}\text { Abr' colonies } \\
\text { recovered } \\
\text { (mean no./plate) }\end{array}$ \\
\hline 0 & $\begin{array}{l}1 \times 10^{5} \\
5 \times 10^{5}\end{array}$ & 0 \\
$1 \times 10^{6}$ & 0.3 \\
& 0 & 1 \\
100 & $1 \times 10^{5}$ & 30 \\
& $5 \times 10^{5}$ & 34 \\
& $1 \times 10^{5}$ & 37 \\
200 & 0 & 55 \\
& $1 \times 10^{5}$ & 63 \\
& $5 \times 10^{5}$ & 71 \\
$1 \times 10^{6}$ & 70
\end{tabular}

${ }^{a}$ The selective medium contained $0.1 \mu \mathrm{g} / \mathrm{ml}$ of abrin. 
Table 3. Expression time of Abrr variants ${ }^{a}$

\begin{tabular}{ll}
$\begin{array}{l}\text { Expression time } \\
\text { (days) }\end{array}$ & $\begin{array}{l}\text { Frequency of } \\
\text { Abr' }{ }^{\mathrm{v}} \text { variants } \\
\left(\times 10^{-5}\right)\end{array}$ \\
\hline 0 & 0.1 \\
2 & 0.3 \\
4 & 1.2 \\
6 & 3.3 \\
8 & 24.3 \\
10 & 8.6 \\
12 & 6.7 \\
\hline
\end{tabular}

"Cells were treated with $200 \mu \mathrm{g} / \mathrm{ml}$ of EMS for $17 \mathrm{~h}$ and grown in non-selective medium for different days before being plated in medium containing $0.1 \mu \mathrm{g} / \mathrm{ml}$ of abrin.

cating that the cells can only be resistant up to the abrin concentrations at which they were selected.

\section{Selection conditions and rate of occurrence of resistant colonies}

The effect of cell density on the recovery of spontaneous and EMS-induced $\mathrm{Abr}^{\mathrm{r}}$ variants was investigated. As shown in table 2, the recovery of variants was not affected by the presence of wild-type cells at a density as high as $1 \times 10^{6} / 100 \mathrm{~mm}$ plate. Hence, under these conditions there is no crossfeeding resulting in a loss of variants in the presence of high densities of parental cells, as it was the case in the 6-thioguanine or 8 -azaguanine selective system [26, 27]. Based on these results, a cell density of $5 \times 10^{5} / 100 \mathrm{~mm}$ plate was chosen for subsequent experiments.

The optimal time required for the expression of the $\mathrm{Abr}^{\mathrm{r}}$ phenotype was examined by determining the frequency of resistant variants at various times after treatment of CHO cells with $200 \mu \mathrm{g} / \mathrm{ml}$ of EMS (table 3). Maximum recovery was observed at 8 days after EMS treatment. Variant frequencies steadily declined after 8 days, presumably due to a reduced fitness of variant cells
Table 4. Fluctuation analysis of changes to abrin resistance in $\mathrm{CHO}$ cells

\begin{tabular}{lcc} 
No. replicate cultures & 20 & 1 \\
No. samplings/culture & 1 & 20 \\
Initial no. cells/replicate & 100 & - \\
Final no. cells/replicate & $1.4 \times 10^{7}$ & $5 \times 10^{6}$ \\
No. of replicates with $N$ Abr ${ }^{r}$ & & \\
colonies & 15 & 11 \\
$N=0$ & 1 & 4 \\
1 & 1 & 4 \\
2 & 0 & 1 \\
3 & 1 & 0 \\
4 & 1 & 0 \\
9 & 1 & 9 \\
25 & 2.1 & 0.75 \\
Average Abr ${ }^{r}$ colonies/culture & 33.84 & 0.93 \\
Variance & & \\
Fraction of cultures with zero & 0.75 & 0.55 \\
Abr colonies & & \\
Rate of occurrence (variants/ & & \\
cell/generation) & & \\
$a^{\prime \prime}$ & \\
$b^{b}$ & $4.1 \times 10^{-8}$ & \\
\hline
\end{tabular}

a From eq. (5) of Luria \& Delbrück [28].

- According to DeMars \& Held [29].

The experiment was initiated by inoculating replicate cultures at about 100 cells each in $100 \mathrm{~mm}$ plate. Following 10 days growth at $37^{\circ} \mathrm{C}$, the colonies were dispersed with trypsin and allowed to grow till confluent. The cultures were trypsinized; the cells were counted. Cells were then seeded in the selective medium containing $0.1 \mu \mathrm{g} / \mathrm{ml}$ of abrin at $5 \times 10^{5}$ cells/ $100 \mathrm{~mm}$ plate and incubated for 10 days at $37^{\circ} \mathrm{C}$. The plates were stained and colonies counted.

compared with wild-type cells in the mixed population.

The rate of spontaneous incidence to abrin resistance in independent cultures was estimated by Luria-Delbrück fluctuation analysis. As shown in table 4 , the rate for the occurrence of $\mathrm{Abr}^{\mathrm{r}}$ colonies was $4.0-7.1 \times 10^{-8} /$ cell/generation.

\section{Characteristics of $\mathrm{Abr}^{r}$ cells}

The cell morphology of the variant clones was essentially the same as the wild-type, being fibroblast-like. The plating efficiency was in the normal range of the wild-type cells $(80-95 \%)$. Variant clone 6A3 grew somewhat slower, having an average gen- 
Table 5. Sensitivity of $\mathrm{CHO}$ wild-type cells, abrin-resistant variants and c'll hybrids to abrin

+ denotes normal cell growth. - denotes cell death

\begin{tabular}{|c|c|c|c|c|}
\hline \multirow[b]{2}{*}{ Cell line } & \multirow{2}{*}{$\begin{array}{l}\text { Modal } \\
\text { chromosome } \\
\text { no. }\end{array}$} & \multicolumn{3}{|c|}{$\begin{array}{l}\text { Sensitivity to abrin } \\
(\mu \mathrm{g} / \mathrm{ml})\end{array}$} \\
\hline & & $2 \times 10^{-3}$ & $1 \times 10^{-2}$ & $1 \times 10^{-1}$ \\
\hline \multicolumn{5}{|l|}{ Parental } \\
\hline $\operatorname{Abr}^{\prime}\left(\mathrm{Gat}^{-}\right)$ & 20 & - & - & - \\
\hline $\mathrm{Abr}^{\mathrm{r}}-1\left(\mathrm{Pro}^{-}\right)$ & 19 & T & - & - \\
\hline $\mathrm{Abr}^{\mathrm{r}}-2\left(\mathrm{Pro}^{-}\right)$ & 20 & + & + & - \\
\hline $\mathrm{Abr}^{\mathrm{r}}-3\left(\right.$ Pro $\left.^{-}\right)$ & 19 & + & + & + \\
\hline \multicolumn{5}{|l|}{ Fusion hybrids } \\
\hline$A b r^{s} \times A_{b r} r^{r}-1$ & 38 & - & - & - \\
\hline$A b r^{5} \times A b r^{r}-2$ & 39 & - & - & - \\
\hline$A b r^{5} \times A b r^{r}-3$ & 38 & - & - & - \\
\hline
\end{tabular}

eration time of $16 \mathrm{~h}$, as compared with $12 \mathrm{~h}$ for the wild-type cells. The growth rates of other variants were not determined.

When cells resistant to different levels of abrin were fused with the wild-type sensitive cells, all 20 cell hybrids tested were sensitive to the toxin (table 5), indicating that abrin resistance behaves as a recessive character.

$A b r^{r}$ cells resistant to different levels of abrin $(0.1-1 \mu \mathrm{g} / \mathrm{ml})$ were found to be resistant to ricin to the same extent as abrin. suggesting that $\mathrm{Abr}^{\mathrm{r}}$ cells may have similar mechanism(s) of resistance to abrin and ricin.

\section{Protein synthesis in intact cells}

The inhibition by abrin of $\left[{ }^{14} \mathrm{C}\right]$ leucine incorporation into protein in normal and variant cells were compared (fig. 3). In this whole-cell assay system, cells were exposed to the toxin for $24 \mathrm{~h}$ before being allowed to incorporate $\left[{ }^{14} \mathrm{C}\right]$ leucine for $1 \mathrm{~h}$. The $\left[{ }^{14} \mathrm{C}\right]$ leucine incorporation in the absence of the toxin was taken as $100 \%$. The two variant clones were less sensitive than the parental cells to the inhibitory effect of abrin but their resistance declined at increasing concentrations of the toxin, indicating the protein synthesis in these two variant lines was also inhibited by abrin.

\section{Binding properties}

In a qualitative binding experiment, the $\mathrm{CHO}$ parental cells and $\mathrm{Abr}^{\mathrm{i}}$ cells were exposed to fluorescein-labeled abrin, ricin, or BS II. The cells were treated with the fluorescein isothiocyanate (FITC)-conjugated toxins for $1 \mathrm{~h}$ at $4^{\circ} \mathrm{C}$, and the fluorescence emitting from the cell surface was observed under a microscope. There was a strong binding of tluorescein-labeled abrin and ricin to parental cells but no observable fluorescence with threc resistant clones tested (6A3, D4-1 and D4-1 $b$ ). BSII, a lectin specific for terminal $N$-acetyl-D-glucosaminyl units, did not bind to parental cells, but did so to all three variants. The binding property of a cell hybrid (Gat ${ }^{-} \times$ 6A3) was identical with the parental, abrinsensitive $\mathrm{Gat}^{-}$of $\mathrm{CHO}$ KI TI cells. These results suggest that the galactosyl residues of the abrin receptor in the variant cells have been deleted, exposing the penulti- 


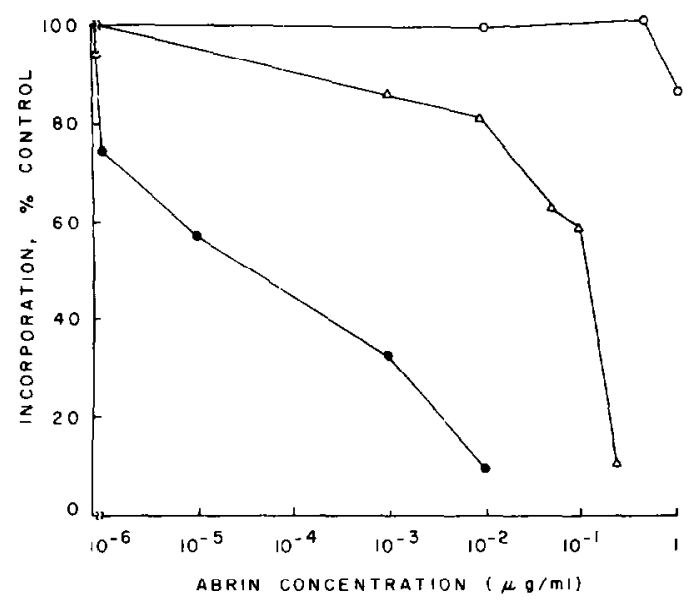

Fig. 3. Inhibition of $\left[{ }^{1+} \mathrm{C}\right]$ leucine incorporation by abrin in sensitive and resistant CHO cells. In this whole-cell assay cells were exposed to abrin for $24 \mathrm{~h}$ and allowed to incorporate the radioactive amino acid for $1 \mathrm{~h}$. O, $\mathrm{Abr}^{\mathrm{s}} \mathrm{CHO} \mathrm{K} 1-\mathrm{Tl}$ cells: O, Abr ${ }^{\mathrm{r}} \mathrm{D} 4-1$ cells; $\triangle . A \mathrm{br}^{5} 6 \mathrm{~A} 3$ cells. The average cpm for the zero time were 103000,75000 , and 110000 for the parental cells, 6A3, and D4-1 respectively.

mate $N$-acetyl-D-glucosaminyl residues on the cell surface. In a quantitative binding assay, cells were treated with FITC-conjugated abrin or ricin in the presence or absence of a competing sugar, galactose or

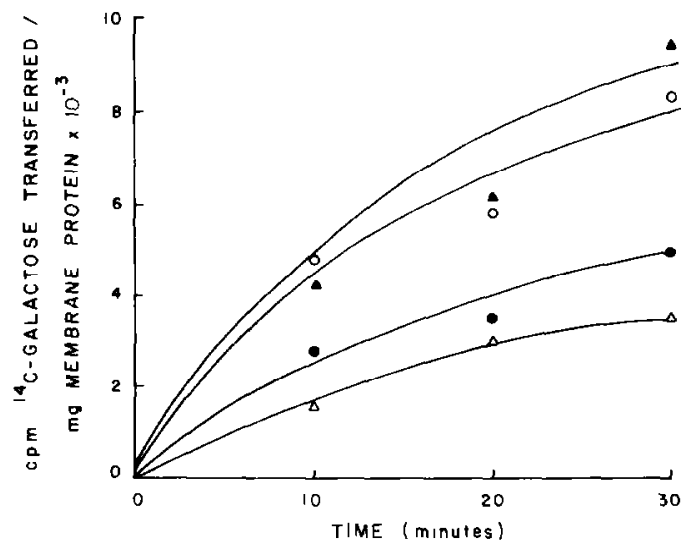

Fig. 4. Galactosyl transferase activity toward endogenous acceptors. Details concerning enzyme preparations and assay conditions are described in the text. -, Parental CHO K1-T1 cells; $\triangle, 6 A 3$ cells; $O$, D4-1 cells; $\Delta$, D4- I $b$ cells. Points represent the average of triplicate determinations.
Table 6. Rate of $\left[{ }^{14} \mathrm{C}\right]$ galactose transfer to exogenously added asialoagalactofetuin

\begin{tabular}{lrl} 
Cell type & Rate $^{a} \pm$ S.D. & $\begin{array}{l}\text { Fold parental } \\
\text { cells }\end{array}$ \\
\hline CHO K1-T1 & $68.7 \pm 0.3$ & 1 \\
GA3 & $116.3 \pm 1.4$ & 1.7 \\
D41 & $94.8 \pm 1.7$ & 1.4 \\
D4 $b$ & $101.9 \pm 1.6$ & 1.5
\end{tabular}

a Rate is expressed as pmoles galactose transferred to $50 \mu \mathrm{l}$ insolubilized acceptor $/ \mathrm{h} / \mathrm{mg}$ membrane protein. The specific activity of the $\left[{ }^{14} \mathrm{C}\right]$ galactose used in these experiments was $600 \mathrm{cpm} / \mathrm{pmole}$.

lactose. After $1 \mathrm{~h}$ of treatment at $4^{\circ} \mathrm{C}$ the bound abrin or ricin were eluted off the membrane and the intensity of fluorescence was determined in a fluorometer. Within the sensitivity of our assay system, binding of abrin or ricin to a resistant clone, D4$1 b$, could not be detected. In contrast, abrin and ricin bind to the parental cells at 7 and $28 \mathrm{ng} / 10^{5}$ cells, respectively.

Galactosyl transferase activity

Cell-free galactosyl transferase assays were carried out using membrane preparations from wild-type or variant cell lines. All cell types tested had the ability to transfer galactose to the exogenously added acceptor asialoagalactofetuin, as shown in table 6 . Thus, the activity of the $\beta$-galactosyl transferase enzymes does not seem to be deficient in the abrin resistant cell lines. In fact, all cell types resistant to abrin showed a reproducibly higher galactosyl transferase activity than did wild-type cells.

The amount of endogenous galactosyl transferase acceptors present in the various crude membrane fractions was determined by quantitation of the $\left[{ }^{14} \mathrm{C}\right]$ galactose incorporated into the glycoproteins of this fraction. These results are shown in fig. 4. Membrane from wild-type and 6A3 cells 
were able to incorporate only low levels of galactose. Clones D4-1 and D4- $1 h$ had proportionally higher amounts of endogenous acceptors in their membrane fractions.

\section{DISCUSSION}

The results presented here indicate that $\mathrm{CHO}$ cells resistant to the toxin from Abrus precatorius may be selected with ease and simplicity. The frequency and rate of occurrence of $\mathrm{Abr}^{\mathrm{r}}$ colonies were compatible with other marker systems [30-32]. There was no effect of cell density or cross feeding on the recovery of variants. The frequency of resistant variants increased linearly with the concentrations of mutagen within the range tested. The Abr' phenotype appeared stable and heritable, since resistance persisted in clones tested after more than 300 generations of growth in the absence of the selective agent. Thus, the change from sensitivity to resistance in these variants could be the result of mutational events rather than adaptation.

The resistance of these variants to one level of abrin at which they were selected may be overcome by increasing the concentration of the toxin. as shown in fig. 2. In this respect, the behavior of our abrinresistant variants is similar to that of the class I diphtheria toxin (DT)-resistant mutants of CHO cells, isolated by Moehring \& Moehring [33, 34], which are resistant at the level of the plasma membrane. The abrinresistant variants isolated in our studies. like class I DT mutants, did indeed exhibit cell surface alterations.

The B subunit of abrin binds specifically to membrane receptors containing nonreducing terminal galactosyl residues [18]. If terminal galactose residues are not available for interaction with the $B$ subunit of the toxin, abrin cannot bind to the cell sur- face and the $A$ subunit is therefore unable to enter the cell and inhibit protein synthesis. This kind of mutation is found in ricinresistant HeLa cells, where the resistance is due to a reduction in the total number of cell surface-binding sites [12]. In a qualitative experiment using fluorescein-labeled abrin and ricin, we found a strong binding of both toxins to parental cell types but no observable fluorescence with the three resistant clones. A fluorescein-conjugated lectin. BS II. which is specific for terminal $N$-acetyl-D-glucosaminyl residues, did not interact with wild-type cells, but did interact with all three mutants, albeit weakly with clone $6 \mathrm{~A} 3$. Since $N$-acetyl-D-glucosaminyl residues are often found subterminal to galactose on oligosaccharide side chains of plasma membrane proteins [21,35,36]. these binding studies. taken together, suggest that galactose has been deleted from the surface of the variant cells. This conclusion is further substantiated by the cellfree galactosyl transferase assays performed using endogenous and exogenous acceptors.

Membrane-bound galactosyltransferase utilizes non-reducing terminal $N$-acetyl-Dglucosaminyl groups linked to oligosaccharide side chains as an acceptor [37]. The transfer of $\left[{ }^{4} \mathrm{C}\right]$ galactose to endogenous acceptors, i.e., to glycoproteins present in the crude membrane fraction which contain terminal $N$-acetyl-D-glucosaminyl residues, is a function not only of the galactosyl transferase levels, but also of the amount of endogenous acceptor present. The galactosyl transferase assay described here allows us to examine both variables in the crude membrane fraction: (1) the levels of enzyme; (2) the amount of cndogenous acceptor. Quantitation of the level of enzyme is achieved by monitoring the rate of transfer of $\left[{ }^{14} \mathrm{C}\right]$ galactose to exogenous- 
ly added acceptor (asialoagalacto-fetuin) which is present in great excess in our assay. As shown in table 6 , the rates of galactosyl transfer are similar in all the abrin-resistant cell types tested. with levels ranging from 1.4 to 1.7 times wild-type values.

Since we find approximately equal levels of enzyme in all crude membrane fractions, the $\left[{ }^{14} \mathrm{C}\right]$ galactose transferred to endogenous acceptors can be taken as a measure of the amount of endogenous acceptor present in crude membrane fraction. As shown in fig. 4 , after $30 \mathrm{~min}$ of incubation membrane fractions from D4-1 and D4- $1 b$ cells transferred 1.7- and 1.9-fold more galactose, respectively, into endogenous acceptors. The number of available acceptor sites for galactosyl transfer in the toxinresistant clones was proportional to their degree of abrin resistance. Clone D4- $b$, which is resistant to the highest levels of abrin $(10 \mu \mathrm{g} / \mathrm{ml})$ contains the largest number of galactosyl acceptor sites; membranes from clone D4-1 (resistant to $1 \mu \mathrm{g} / \mathrm{ml}$ ) and 6A3 (resistant to $0.1 \mu \mathrm{g} / \mathrm{ml}$ ) have proportionately less galactosyl transferase activity toward endogenous acceptors. In this respect, clones D4- 1 and D4-1 $b$ are similar to a wheat germ agglutinin (WGA)-resistant cell line (clone 13) isolated from $\mathrm{CHO}$ cells by Briles et al. [5]. In that cell line, the galactosyl transferase activity toward asialoagalactofetuin is 1.7 times the wild-type value and the cells have 4.6 times more galactosyl acceptor sites on their cell surfaces; it also exhibits a reduced amount of terminal galactose on its plasma membranes.

Theoretically, there are at least three possible mechanisms of cell resistance to abrin or ricin. First, the resistance may be due to a reduced amount of toxin-binding sites on the cell surface. So far, all the ricin-resistant mutants isolated from $\mathrm{HeLa}$ cells [12] and from $\mathrm{CHO}$ cells [1] and our abrin-resistant variants are of this kind. The second mechanism of resistance due to an impaired uptake of toxin has not yet been described. However, this type of permeability variants has been postulated to be the case in those ricin-resistant cell lines isolated by Hyman et al. [38] and Meager et al. [4], which were shown to exhibit little reduction in the number of toxinbinding sites. Finally, translational variants with altered GTPase on the ribosome which is insensitive to the inhibitory effects of abrin or ricin could be the third mechanism of cell resistance to the toxins, but such type of cell variants have not yet been reported, as far as we are aware.

This work was supported by US Department of Energy Contract No. EY-76-C-02-2828 and USPHS grants GM 20608 and CA-017952. D.A.B. was supported by USPHS Fellowship F32CA06172. We thank Barry Peters for advice on the membrane fluorescence study. Barbara Lamb and Judy Maw for technical assistance, and Wayne Stanley and Dennis Yep for many helpful discussions.

\section{REFERENCES}

1. Gottlieb, C, Skinner, A \& Kornfeld, S, Proc natl acad sci US 7! (1974) 1078.

2. Gottlieb, C, Baenziger, J \& Kornfeld, S. J biol chem 250 (1975) 3303.

3. Stanley, P, Caillibot, V \& Siminovitch. L, Somat cell genet 1 (1975) 3.

4. Meager, A, Ungkitchanukit, A, Nairn, P \& Hughes, R. Nature 257 (1975) 137.

5. Briles. E. Li, E \& Kornfeld, S, J biol chem 252 (1977) 1107

6. Stanley, P \& Siminovitch, L, Somat cell genet 3 (1977) 391

7. Kornfeld, R \& Kornfeld, S, Ann rev biochem 45 (1976) 217.

8. Briles, E \& Kornfeld, S, Trends biochem sci 3 (1978) 223

9. Olsnes, S \& Pihl, A, Receptors and recognition series $B$ : The specificity and action of animal. bacterial and plant toxins (ed P Cuatrecasas) pp. 130-173. Chapman \& Hall, London (1976).

10. Olsnes, S \& Pihl, A, Nature 238 (1972) 459

11. Benson, S. Olsnes, S \& Pihl, A, Eur j biochem 59 (1975) 573.

12. Fodstad, 0 . Olsnes, S \& Pihl, A, Cancer res 37 (1977) 4559 . 
13. Sandvig. K, Olsnes, S \& Pihl, A, Eur j biochem 82 (1978) 13 .

14. Olsnes, S \& Refsnes. K. Eur j biochem 88 (1978) 7.

15. Pappenheimer. A, Olsnes, S \& Harper, A. J immunol 113 (1974) 835 .

16. Olsnes, S. Saltvedt. E \& Pihl. A, J biochem chem 249 (1974) 803

17. Olsnes. S. Refsnes, K. Christensen, T \& Pihl. A. Biochim biophys acta 405 (1975) I.

18. Goldstein. I J \& Hayes, C E. Adv carbohyd chem \& biochem 35 (1978) 128.

19. McBurney, M \& Whitmore, G, Cell 2 (1974) 173.

20. Ebisu. S \& Goldstein. I J, Methods enzymol 50 (1977) 350 .

21. Baenziger, J U \& Fiete, D. J biol chem 254 (1975) 789.

22. Warren, L, J biol chem 234 (1959) 1971.

23. Meisler, M, Methods enzymol 28 (1972) 820 .

24. Kim. J J \& Conrad. H E. J biol chem 249 (1974) 3091 .

25. Blake, D A \& Goldstein. I J. In preparation.

26. Friedman, F, Seegmiller, J \& Subak-Sharpe, J, Nature 220 (1968) 272.

27. van Zeeland, A. van Diggelen, $M$ \& Simons. J. Mutat res 14 (1972) 355.

28. Luria. S \& Delbrück, M. Genetics 28 (1943) 491.
29. DeMars. R \& Held, K. Humangenetik if 11972, 87.

30. Chu. E, Brimer. P. Jacothoon. $k$ d Merrian, E. Genetics 62 (1969) 359.

31. Jones. G \& Sargent, P. Cell $2(1974) 43$

32. DeMars, R, Mutat res $24(1974) 33.5$.

33. Moehring, T \& Moehring. J. Cell 11119771447.

34. Moehring. J \& Moehring. T. Somat cell genet 5 (1979) 453.

35. Tabas. I \& Kornfeld. S. J hiol chem 253 (1978) 7779.

36. Carter, W G \& Hakamori. S. Biochemistry is (1979) 730 .

37. Rao. A K. Garver, F \& Mendicino. J. Biochemistry 15 (1976) $500 \mathrm{l}$.

38. Hyman. R, Lacorbière. M. Stavarek, S \& Nicolson, G. J natl cancer inst 52 (1974) 963.

39. Stanley, P. Caillibot, V \& Siminovitch. L. Cell 6 (1975) 121 .

40. Nicolson, G L. Blaustein. I \& Etzler. E. Biochemistry 13 (1974) 196.

Received January 23, 1980

Revised version received April 24, 1980

Accepted April 29, 1980 